\title{
READING ALASDAIR MACINTYRE'S AFTER VIRTUE
}

Christopher Stephen Lutz, New York: Continiuum International Publishing, 2012, $212 \mathrm{~s}$.

\section{Elif Nur Erkan BALCI*}

Eğer bir filozofun magnum opusunu (şâheserini) okumaya niyetlendiysek basitçe onu temel iddialarıyla anlamak zorundayızdır. İster bunu söz konusu kitabı defalarca okuyarak elde edelim, ister yardımcı kitaplar üzerinden gerçekleştirelim fark etmez. Burada kitabı doğru ya da yanlış anlamak da birincil mesele değildir. Birincil olan şey, söz konusu eserin ne anlattığının bize tamamen açık ve anlaşılır olmasıdır. Çünkü yazarın diğer çalışmaları önemli ölçüde hep söz konusu temel eserindeki iddiaları üzerine yeniden ve yeniden inşa edilecektir.

Alasdair MacIntyre'ın (1929 Glasgow - ) 1981'de After Virtue ismi ile yayınladığ1 ve 2001'de Muttalip Özcan tarafından Erdem Peşinde şeklinde Türkçeye çevrilen kitabı işte bu anlamak zorunda olduğumuz kitaplardan biridir. Kitaba aşina olmayanlar için çok kısa bilgi vermek gerekirse; After Virtue, Aristoteles'ten yola çıkarak ahlak felsefesini yeni baştan inşa etme iddiasını taşıyan, ahlak felsefesinin tarihsel yolculuğunu kendine özgü bir üslupla anlatmaya ve öğretmeye çalışan bir ahlak felsefesi kitabıdır. Eserin muhatapları sadece ahlak felsefesi alanında çalışanlar değil; genel olarak felsefe, sosyoloji, antropoloji, tarih gibi tüm sosyal bilimler alanına profesyonel ya da entelektüel anlamda ilgi gösteren herkestir. Eserin odak noktası, modern dönemle birlikte sosyal bilimlerin elde ettiği pseudo-(sahte) kazanımların yarattığı erozyonun genel olarak felsefe ve özel olarak ahlak felsefesinde nasıl kurgular oluşturduğunu gözler önüne sermektir.

Tanıtımını yaptığımız kitap, felsefe tarihi ve etik alanında dersler veren ve Alasdair MacIntyre üzerinde uzmanlaşmış Profesör Christopher Stephen Lutz'un After Virtue'yi anlama konusunda mükemmel bir yardımcı kitap olarak düşünülebileceğimiz eseridir. Türkçe ya da İngilizce literatürde After Virtue'yi anlatan başka müstakil bir eserin şimdilik mevcut olmaması kitaba ayrı bir önem atfetmektedir. Böyle bir kitaba okuyucu niçin ihtiyaç duyabilir meselesi ise After Virtue'yi okuyanların kolaylıkla iki şekilde cevaplayabileceği bir sorudur. İlk olarak; MacIntyre söz konusu kitabında ele aldığı kişileri, kavramları ve bunlar arasında kurduğu bağlantıları karşısında Batı'nın

* Arş. Gör., Sakarya Üniversitesi, İlahiyat Fakültesi, Felsefe ve Din Bilimleri Bölümü. (elifnurerkanbalci@gmail.com) 
entelektüel tarihine tamamen aşina bir okuyucu kitlesi varsayarak anlatır. Lutz da bu meseleye dikkat çekerek After Virtue'nin iki bin beş yüz yıllık felsefe, tarih, metafizik, siyaset, antropoloji, sosyal bilim hakkında konuştuğunu ifade eder (s.8.).

İkinci olarak; MacIntyre'ın kendi orijinal kavramları ve tanımlamaları yeterince açık değildir. Tüm bu sorunların After Virtue'nin sadece biz 'Doğulu' okuyucularına dair bir sorun olmadığı, Lutz'un bu kitabı yazmasından da kolaylıkla anlaşılabilir. Lutz, kitabı yazma sürecinin bile kendisi için göz korkutucu bir şey olduğunu, çünkü After Virtue'nin çok disiplinli bir kitap olduğunu; felsefe tarihi, modern etik eleştirisi, Marksist politik teori, eylem teorisi ve Karl Marx felsefesini kat eden konuları içerdiğini ifade etmektedir (s. x). Bu kitabı yazma amacının ise After Virtue'nin dünyasına yabancı olanlar için bir başlangıç ve daha sonraki ilgili çalışmalar için sağlıklı bir zemin yaratma olduğunun altını çizer (s.1).

Lutz'un kitabı giriş ve yedi bölümden oluşmaktadır. Giriş bölümünde Lutz, MacIntyre ve After Virtue' ye dair temel meseleleri ortaya koymaktadir. Bu kısmın okuyucuya en önemli katkısı, MacIntyre'ın söz konusu eserine zemin hazırlayan filozoflar ve eserlerinden de bahsedilmiş olmasıdır. Burada ayrıca MacIntyre'ın After Virtue'de kullandığı metot da çok açık ve öz bir şekilde dile getirilmektedir.

Birinci bölümde Lutz, MacIntyre ve Marxism diyalogunu ele alır. MacIntyre'ın Marksizm okuması onun temel felsefesi açısından en temel meseledir. MacIntyre'ın önce Marksizmi benimseyişi, daha sonra Marksizm'i terk etmesinin sebebi onun ahlak felsefesindeki deviniminin bir sonucudur. Bu bölüm bu önemi içinde barındırarak, eylem versus davranış, sosyal bilimler felsefesi ve Marksizm eleştirisi, After Virtue'nin Stalinizm'e dair ahlaki eleştirisinin kökenleri, Marx ve MacIntyre versus bireycilik, Liberalizm, Marksizm ve Aristoteles alt başlıklarını taşımaktadır (s.12-41).

İkinci ve üçüncü bölüm MacIntyre'ın After Virtue'de modern ahlakı nasıl gördüğünü ve ona yönelttiği eleştirileri ele almaktadır. Özellikle üçüncü bölümde Lutz, After Virtue' deki orijinal başlıkları dokuz bölümde tek tek ele alarak yeniden açıklamaktadır (41-70). Dördüncü bölümde MacIntyre'ın After Virtue'deki eleştirilerinin bütünlüklü bir derlemesi yer alır. Burada Lutz, MacIntyre'ın geliştirdiği örneklere yeni örnekler ekleyerek meseleyi okuyucu için daha görünür kılar. Bu bölümde; geleneksel ahlak felsefesi, rölativizm, pratik akıl ve moral yarg1, Duyguculuğun anlam ve kullanıma dair problemi, Duyguculuğun karakterleri, epistemolojiden eyleme geçiş, bilim versus ahlak felsefesi dikotomisi, Nietzsche mi Aristoteles mi haklı idi? gibi MacIntyre'ın eleştirdiği noktaları öz bir şekilde yeniden ortaya koymak- 
tadır (s.75-106). Beşinci bölümde Lutz, MacIntyre'ın bütün bu eleştirilerinin yerine neyi ikame ettiğini açıklar. Aristoteles'i nasıl yapılandırdı̆̆ı, erdem tanımı ve erdem teorisini nasıl uyguladığını özetler (s.107-147).

Altıncı bölüm Lutz'un özgün After Virtue yorumunu bulduğumuz bölümdür. Burada Lutz, After Virtue kitabında desteklediği meselelerin yanı sıra söz konusu eserde iki probleme de işaret eder: MacIntyre'ın erdemlerin birliği tezine karşı çıkması ve zararlı-kötü eylem pratiklerinin de olabileceğine dair tezi. Lutz, bu iki hatalı tezin After Virtue' nin iddiasına nasıl ve niçin zarar verdiğini ve MacIntyre'ın bunu fark ederek bir diğer kitabı olan Whose Justice Which Rationality'de (1988) nasıl düzelttiğini ortaya koyar. Ayrıca bu bölümde Lutz, MacIntyre ve Aristotelyen erdem etiğini savunanların karşısindaki en önemli problem olan Aristoteles'in metafizik biyolojisi meselesini de ele almaktadır. Bu noktada "Aristoteles'in metafiziğini yok sayarak Erdem Etiği nasıl savunulabilir?" meselesi aydınlığa kavuşmaktadır. Burada MacIntyre'ın After Virtue' de geliştirdiği eylem teorisinde metafiziği diskalifiye etmesi ya da görmezden gelmesi ve yerine neyi ikame ettiği meselesi öğreticidir. Son olarak After Virtue'da MacIntyre'ın geliştirdiği erdem etiğinin rölativist, nostaljik, pesimist bir tarafının olup olmadığı Lutz'un kendi bakış açısından ele alınmaktadır. Öyle ki bu meseleler bir çok yorumcu tarafından MacIntyre'ın söz konusu eserine yöneltilen temel eleştiri noktalarındandir (s.148-185).

Yedinci ve son bölüm MacIntyre üzerinde çalışanları fazlasıyla ilgilendirmektedir. Burada After Virtue' den sonra MacIntyre'ın neler yazdı̆̆ı gösterilmekte ve ayrıca MacIntyre hakkında öne çıkan literatür bilgisi sunulmaktadır (s.186-192).

Lutz'un bu öğretici ve oldukça açık eseri, MacIntyre'ın After Virtue'de ortaya koyduğu zihni zorlayıcı fikirleri tek tek çözme ve anlama noktasında yeni ve kullanışlı bir gözlük sunmaktadır. Son olarak şunu da eklemek gerekir ki, kitap sadece After Virtue'yi anlamak isteyenlerin değil ama aynı zamanda kısmen bir Batı Felsefesi Tarihi şerhi okumak isteyenlerin başvurulabileceği bir kaynak olarak da görülebilir. 